\title{
Sweden's Development Lead
}

Written by: Anna Chapman, OECD Observer

Last update: 2 March 2020

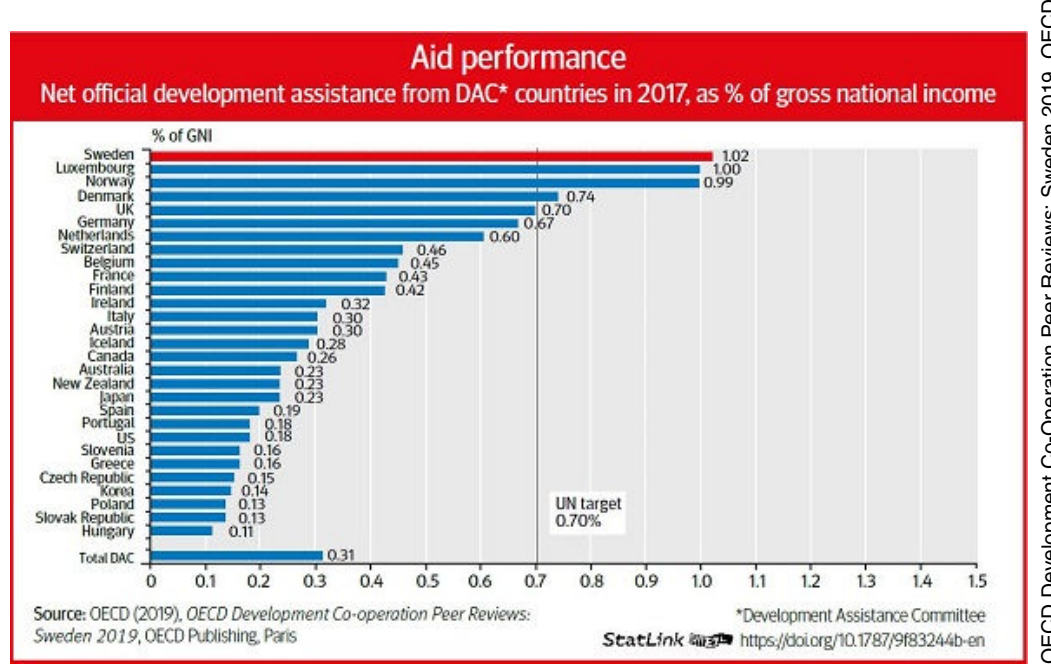

Sweden's development lead chart I Chart for Sweden's development lead

Since 2006, Sweden has delivered $1 \%$ of its gross national income (GNI) as official development assistance (ODA). In 2017, Sweden was the highest contributor in percentage terms among OECD Development Assistance Committee (DAC) countries, outstripping the UN recommended goal of $0.7 \%$ of GNI.

So how do they do it? Both the Swedish public and its government strongly support the country's development commitments, reinforced by the awarenessraising activities of the Ministry of Foreign Affairs and Swedish International Development Co-operation Agency.

Despite facing rising income inequality, housing shortages and house-price inflation, Sweden continues to remain an open country, committed to helping those faced with or fleeing persecution and violence. In 2015, Sweden received 163,000 asylum seekers-the highest number relative to population of all OECD countries.

Sweden continues to provide effective and principled humanitarian efforts with its co-ordinated approach to address the development, humanitarian and peace nexus in fragile and crisis contexts. Moreover, some $87 \%$ of its bilateral allocable 
aid in 2017 had gender equality and women's empowerment as a key or significant objective.

However, as the latest DAC peer review of Sweden's development effort shows, there is some way to go in addressing internal staffing gaps and consolidating its policy framework on development co-operation and humanitarian assistance. Focusing its thinly stretched aid programme on fewer countries could further enhance its impact and reduce pressure on staff.

\section{References}

OECD (2019), OECD Development Co-operation Peer Reviews: Sweden 2019, OECD Publishing, Paris, https://doi.org/10.1787/9f83244b-en. http://dx.doi.org/ 